\title{
スクロースおよびクエン酸を混合した スギ粉末の熱流動に及ぼす粒子サイズの影響†
}

\author{
梶川 翔平* 曺 基宇* 久保木 孝* \\ 田中 聡一 $* *$ 梅村 研二** 金山 公三**
}

\section{Effect of Particle Size on Thermal Flow of Japanese Cedar Powder Combined with Sucrose and Citric Acid}

by

\author{
Shohei KaJIKawa*, Kiu Chо*, Takashi KUвокI*, \\ Soichi TanaKa**, Kenji Umemura** and Kozo Kanayama**
}

This paper proposed molding of wood powder with natural binder, which is composed of sucrose and citric acid, for effectively fabricating wood product without synthetic resins. In the proposed method, optimization of particle size is important for improving the thermal fluidity during the molding and reducing the milling cost. Thermal flow testing of wood powder with natural binder was carried out in order to investigate the effect of particle size on thermal flow of wood powder with natural binder. When binder content was 30 40 $\mathrm{wt} \%$, the thermal flow pressure changed depending on the particle size, and the optimum one was the particles, which passed $2.8 \mathrm{~mm}$ mesh sieve and be on $2.0 \mathrm{~mm}$ mesh sieve, for decreasing the flow pressure. In a case that the particle size was smaller than the optimum size, the flow pressure increased because the slipping plane propagation was prevented. In the case that the particle size was larger than the optimum size, the flow pressure also increased due to an increase in the force for crashing the particles. Based on the results of thermal flow testing, molding testing was carried out. When the particle size was optimum, products were fabricated successfully in a wide range of binder content, which was 30 50 wt $\%$, because the flow pressure was low.

\section{Key words}

Molding, Thermal flow, Wood, Powder, Japanese cedar, Natural binder, Sucrose, Citric acid

1 緒言

プラスチックごみの大量廃棄にともなう海洋污染が問 題となっている. 欧州を中心に, 使い捨てプラスチック削 減のための政策が打ち出されており，2018 年には食卓食 器類，マドラーおよびストローなどの使い捨てプラスチ ックの禁止が提案されている ${ }^{1)}$. そのため, 既存のプラス チックを代替する低環境負荷材料に関する技術開発は急 務である. 低環境負荷材料の 1 つとして, 木質系材料が提 案されている. 特に, 木質系材料は, 計画的な植林および 伐採によって, 持続的な利用が可能である上, カーボンニ ユートラル2)な特性を持つ.

木質系材料をプラスチックの代替材料として利用する ためには, 製造技術の効率化が必要である.プラスチック 材料はプレス成形，射出成形および押出し成形などによ って様々な形状に加工できるため, 大量生産が可能であ る ${ }^{3)}$ 。これに対し，木質系材料は個体差が大きく，異方性 も有するため, プラスチックと比べて加工が難しい. 混錬 型木質・プラスチック複合材（混錬型 WPC）など，プラ スチックと同様の手法で成形加工できる手法も開発され
ているが，成形時において木質系粉末を流動および接着 させるバインダとして，ポリプロピレンやポリエチレン などの石油由来の熱可塑性樹脂を多く使用する ${ }^{4)}$.

木質系粉末のみを用いて, 成形加工寸る手法も研究が 進められている. 適切な水分・温度状態下にて加熱処理さ れた木質系粉末は, 熱流動性や自己接着性を示し, 成形加 工が可能であることが明らかになっている5)-8). しかしな がら, 成形時における木質系粉末の熱流動性がそしく, 安 定的に製品を得ることが難しい. 一方, 木質系粉末の熱流 動性は, 構成成分の加水分解によって生成された糖類に よって, もたらされる ${ }^{9)}$. したがって, バインダとして糖 類を木質系粉末に添加すると，木質系粉末の熱流動性が 向上し, 成形不良の抑制, ならびに成形品の物性向上につ ながると考えられる。

著者らは，これまでに代表的な糖であるスクロースや， スクロースに対してクエン酸を混合したものをそれぞれ 天然系のバインダとして用い，木質系粉末を成形加工す る手法を提案した ${ }^{10), 11)}$. 本手法にて用いる天然系バイン ダは, 加熱によって, 溶融および分解反応が生じる. 過度

$\dagger$ 原稿受理 令和元年 11月 11日 Received Nov. 11, 2019 C2020 The Society of Materials Science, Japan

* 正会員電気通信大学 大学院情報理工学研究科 機械知能システム学専攻 テ182-8585 調布市調布ヶ丘 Dept. of Mechanical and Intelligent Systems Engineering, The University of Electro-Communications, Chofu Gaoka, Chofu 182-8585.

** 京都大学 生存圈研究所 $=611-0011$ 宇治市五ヶ庄

Research Institute for Sustainable Humanosphere, Kyoto University, Gokasho, Uji 611-0011. 
に分解反応が進むと成分の揮発が生じるため, 成形に悪 影響を及ぼす。このため, 溶融時に分解反応をともなわな い一般的な熱可塑性樹脂と比べ, 温度調整が極めて重要 である.これまでに, 適切に温度を調整することによって 木粉が良好に流動し, 高い強度・耐水性を有する成形品を 得られることを確認した. 特に, スクロース・クエン酸混 合物をバインダとして用いた場合, クエン酸によって糖 類が加水分解され低分子化することによって ${ }^{12)}$ ，高い熱 流動性が発現する.さらに, 糖類とクエン酸がエステル結 合することによって，成形品に強度および而水性をもた らす 13),14)。このため, 本手法は有効であり, 成形品は既存 のプラスチックの代替として利用できる可能性がある.

一方, 提案手法における適切な木粉の粒子サイズは, 明

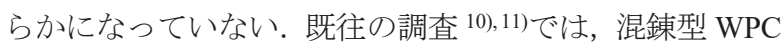
の場合と同様に, 微粉砕した木粉を使用してきたが, 木粉 の微粉砕にはコストがかかる. 粒子が大きい場合, 木材が 元々有している繊維構造がある程度残存するため, 繊維 強化によって, 成形品の強度が向上する可能性もある.

本研究では，木粉の粒子サイズが熱流動性に及ぼす影 響を調査した. 様々な粒子サイズの木粉に対して, スクロ 一スおよびクエン酸から構成されるバインダを混合し, ノズルを用いた流動試験を実施することによって，熱流 動性が高まる粒子サイズを明らかにした．また, 試験結果 を考察するため, 流動時の試料の断面を観察した. さらに, 成形試験を実施し，板状の成形品を作製することによっ て, 熱流動試験結果の妥当性を検証した.

\section{2 供 試 材 料}

木質系素材として，（株）島田小割製材所にて作製され たスギチップ（東京産・樹皮なし）を使用した．辺材や心 材の区別はされていない. 粉砕機（大阪ケミカル（株）製 ワンダーブレンダーD3V-10）を用いてチップを粉砕した 後に, 目開きが異なる 6 種類のふるいを用いてふるい分 けした木粉を実験に使用した. Table 1 に，木粉粒子のサ イズを示す. 本実験では, 木粉の粒子サイズ $d$ を, 粒子が 残存したふるいの目開き $d_{1}$, および通過したふるいの目 開き $d_{2}$ を用いて，以下の式にて定義した。

$$
d=\frac{d_{2}+d_{1}}{2}
$$

Fig. 1 (a) (c)に代表的な木粉外観を示す. 粒子を拡大して 観察すると, Fig. 1 (d) に示すように, 䋊維状の仮道管か ら構成されていた，粒子の表面も繊維方向と一致してお り，粉砕時に仮道管に沿って割れたことがわかる.

バインダとして, スクロースとクエン酸（無水）の混合 物を使用した。 なお，スクロースおよびクエン酸はいずれ もナカライテスク（株）にて製造されたものを使用し，混 合比は 1:1 とした.

木粉とバインダの混合方法について説明する.まず，材 料の含水状態を一定とするため, $80^{\circ} \mathrm{C}$ の送風乾燥器 (ヤマ 卜科学 (株) 製, 送風定温乾燥器 DK340S) にて 24 時間,
Table 1 Particle size of wood powder.

\begin{tabular}{|c|c|c|}
\hline Particle size $d[\mathrm{~mm}]$ & \multicolumn{2}{|c|}{ Sieve opening $[\mathrm{mm}]$} \\
\cline { 2 - 3 } & Mesh on $d_{1}$ & Mesh pass $d_{2}$ \\
\hline 0.25 & 0 (None) & 0.5 \\
\hline 0.75 & 0.5 & 1.0 \\
\hline 1.5 & 1.0 & 2.0 \\
\hline 2.4 & 2.0 & 2.8 \\
\hline 3.4 & 2.8 & 4.0 \\
\hline 4.8 & 4.0 & 5.6 \\
\hline
\end{tabular}

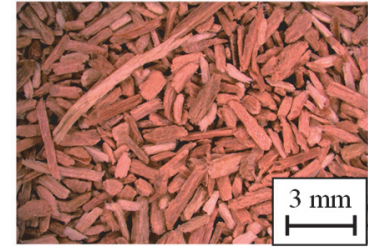

(a) $d=0.75 \mathrm{~mm}(20 \mathrm{x})$

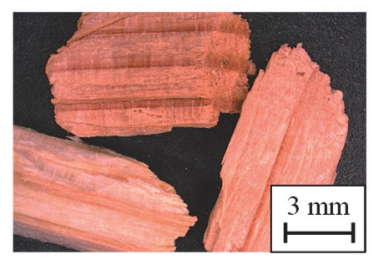

(c) $d=4.8 \mathrm{~mm}(20 \mathrm{x})$

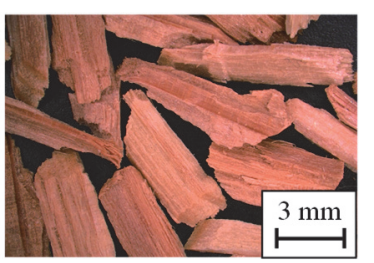

(b) $d=2.4 \mathrm{~mm}(20 \mathrm{x})$

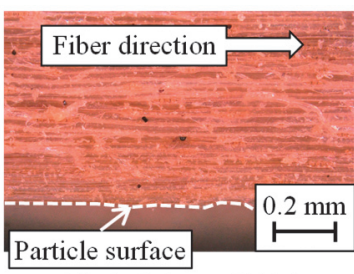

(d) $d=2.4 \mathrm{~mm}(300 \mathrm{x})$
Fig. 1 Appearances of powder.

木粉およびバインダを乾燥した. その後, 所定の濃度にな るようバインダを溶かした水溶液に, 木粉を投入し, 攪拌 することによって, 木粉とバインダを混合した。攪拌後, 再び $80^{\circ} \mathrm{C}$ の送風乾燥器にて 48 時間乾燥することによっ て試料を得た。試料のバインダ含有率 $B$ を $20,30,40$ およ び $50 \mathrm{wt} \%$ にするた，混合時におけるバインダ水溶液の 濃度は，3.8，5.7，7.4および $9.1 \mathrm{wt} \%$ に調製した。

\section{3 熱 流 動 試 験}

\section{$3 \cdot 1$ 熱流動試験方法}

熱流動試験には，当研究室にて作製した装置を使用し た. Fig. 2 に装置の概略を示す.パンチおよびノズルには, 合金工具鋼 (SKD11), それ以外の部品については機械構 造用炭素鋼 (S45C) を用いた. 試料を Fig. 2 (a) に示す) ズルから押し出し，その際の荷重の変化を測定すること によって, 試料の熱流動性を評価した。

試験手順としては, まず試料をコンテナに投入し, 所定 時間 $t_{\mathrm{h}}$ 予熱した。予熱後，パンチを一定速度 $v_{\mathrm{p}}$ にて押し 込むことによって, 試料をノズルから押し出した. 試料が 流出する際におけるパンチ面圧挙動の概略を Fig. 2 (b) に 示す. まず, パンチの押し込みによって, 試料はノズルか ら押し出されることなく圧縮され, それにともなってパ ンチ面圧は上昇する. 所定の面圧まで上昇すると, 試料は ノズルから流出し始める. この時, 面圧の急激な上昇がス トップし，その後は面圧が上下しながら推移する. 本実験 では, 流出開始時のパンチストローク $s$ を $0 \mathrm{~mm}$ とした上 で， $s=5 \sim 15 \mathrm{~mm}$ の区間（Fig. 2 (b)）における平均面圧 $P_{\mathrm{a}}$ を 


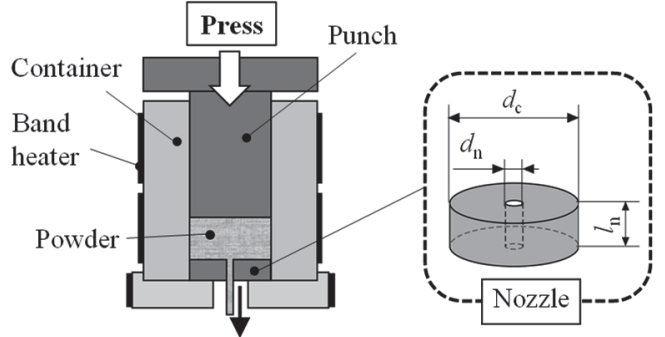

(a) Schematic of flow test

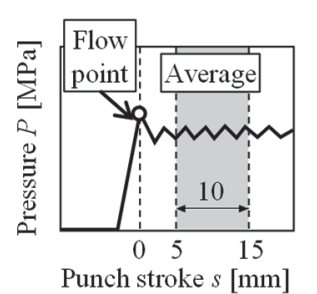

(b) Flow curve

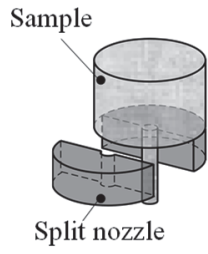

(i) Sample (c) Observation of cross section

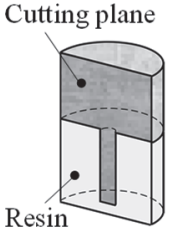

(ii) $\mathrm{Cut}$
Table 2 Thermal flow test conditions.

\begin{tabular}{|c|c|}
\hline $\begin{array}{c}\text { Container inner diameter } d_{\mathrm{c}} \\
{[\mathrm{mm}]}\end{array}$ & 30 \\
\hline Nozzle diameter $d_{\mathrm{n}}[\mathrm{mm}]$ & 2,4 \\
\hline Nozzle length $l_{\mathrm{n}}[\mathrm{mm}]$ & 10 \\
\hline Punch velocity $v_{\mathrm{p}}[\mathrm{mm} / \mathrm{s}]$ & 0.1 \\
\hline Temperature $T\left[{ }^{\circ} \mathrm{C}\right]$ & 180 \\
\hline Pre-heating time $t_{\mathrm{h}}[\mathrm{min}]$ & 5 \\
\hline Mass of sample $m[\mathrm{~g}]$ & 30 \\
\hline Particle size of wood $d[\mathrm{~mm}]$ & $0.25,0.75,1.5,2.4,3.4,4.8$ \\
\hline Binder content $B[\mathrm{wt} \%]$ & $30,40,50$ \\
\hline Maximum pressure $P_{\max }[\mathrm{MPa}]$ & 200 \\
\hline
\end{tabular}

求め, 熱流動性を評価した. $P$ a が低いほじ, 試料の熱流動 性が高いと考えた。 最大面圧 $P_{\max }$ を加えても, 試料が流 出しない場合は, 流出不可とした。

Table 2 に熱流動試験の条件を示寸. 試験温度 $T$ は既往 の調査 ${ }^{11}$ に基づき, 試料が最も良好に流動する $180^{\circ} \mathrm{C}$

とした. パラメータとして, 木粉の粒子サイズ $d$ およびバ インダ含有率 $B$ を変化させた.

\section{$3 \cdot 2$ 試料の断面観察方法}

流動時における粒子の状態を調査するため, 試験を途 中で中断し，コンテナ部およびノズル部に残存した試料 の断面観察を行った. 観察用試料を装置から容易に取り 出すため, Fig. 2 (c) (i) に示すようなノズル径 $d_{\mathrm{n}}=4 \mathrm{~mm}$ の 割型ノズルを使用した. 試料を取り出した後に，ノズル部 が割れないようにエポキシ樹脂（日産レジン（株）製，ク リスタルレジン）に埋めた状態で試料を半分に切断した

(Fig. 2 (c)). 切断面を粒度 P60，P400 および P800 の研磨 紙にて研磨後, マイクロスコープ（(株）キーエンス製, VHX900F）にて観察した.

$3 \cdot 3$ 流動時のパンチ面圧に及ぼす粒子サイズの影響 ノズル径 $d_{\mathrm{n}}=2 \mathrm{~mm}$ の場合において, 粒子サイズ $d$ がパ

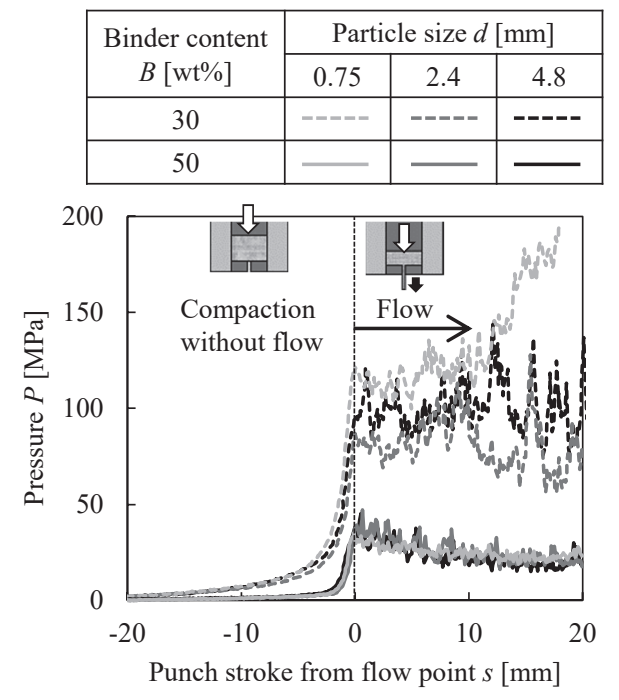

Fig. 3 Effect of particle size $d$ on thermal flow curve $\left(T=180^{\circ} \mathrm{C}, d_{\mathrm{n}}=2 \mathrm{~mm}\right)$.

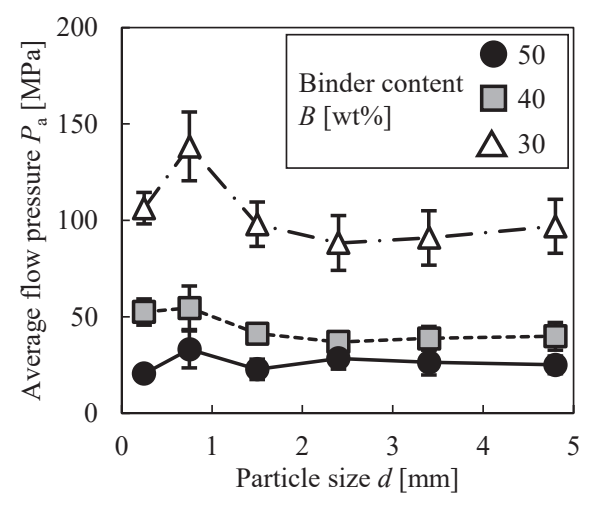

Fig. 4 Effect of particle size $d$ on average flow pressure $\left(T=180^{\circ} \mathrm{C}, d_{\mathrm{n}}=2 \mathrm{~mm}\right)$.

ンチ面圧 $P$ の挙動に及ぼす影響を Fig. 3 に示す. バイン ダ含有率 $B=50 \mathrm{wt} \%$ の場合，いずれの $d$ においても良好に 流動した. $d$ の影響はほとんど見られず, 試料流出時にお ける $P$ はおおよ之一定にて推移した. 特に, ノズル径 $d_{\mathrm{n}}$ よりも大きい $d$ においても良好に流動した.これは, 試料 がノズルに流入する際に，粒子が破砕したためだと考え られる. $B=30 \mathrm{wt} \%$ の場合も, 全ての $d$ において試料はノ ズルから流出した. 一方, 流出時の $P$ は激しく上下し, な おかつdによってその大きさは変化した.

Fig. 4 に粒子サイズ $d$ が試料流出時の平均面圧 $P_{\mathrm{a}}$ に及 ぼす影響を示す。バインダ含有率 $B$ が多い場合 $(B=50$ $\mathrm{wt} \%), d$ が $P$ a に朗響は小さい。一方， $B$ が 30〜 40 $\mathrm{wt} \%$ まで少なくなると， $d$ が小さい条件にて $P_{\mathrm{a}}$ が高くな り, 特に $d=0.75 \mathrm{~mm}$ にてピークを示した. $d$ がさらに大き くなると $P_{\mathrm{a}}$ は低下し,$d=2.4 \mathrm{~mm}$ 近傍にて最小となる. $d=2.4 \mathrm{~mm}$ 以上になると, $P_{\mathrm{a}}$ はゆるやかに増加するものの, $d=0.25$ および $0.75 \mathrm{~mm}$ の場合よりも低い值となった. 上 記の結果を踏まえると，本実験におけるノズル径 $d_{\mathrm{n}}=2.0$ $\mathrm{mm}$ の条件において, 試料の熱流動性が最も高まる粒子サ イズ $d$ は $2.4 \mathrm{~mm}$ である. 
$3 \cdot 4$ 流動時における試料断面の状態

Fig. 5 に，内径 $d_{\mathrm{n}}=4.0 \mathrm{~mm}$ の割型ノズルを用いて，試験 を実施した際の試料断面を示す．試験を中断するまでの パンチ面圧 $P$ は, $d_{\mathrm{n}}=2.0 \mathrm{~mm}$ のノズルを用いた際と同様に 粒子サイズ $d=0.25 \sim 0.75 \mathrm{~mm}$ といった細かい粒子の場合 に大きくなり,$d$ が大きくなるにつれて $P$ が低下する傾向 を示した．Fig. 5 を見ると，いずれの粒子サイズ $d$ におい ても，ノズル部に向から流線が確認された。また， $d$ が大 きい場合，Fig. 5 (c) に示すように，粒子が折れ曲がりな がらノズルへ流入し，䋊維構造がある程度維持されたま まノズル内を流動していく様子が確認された。ノズルへ の流入部近傍の断面に着目すると，粒子サイズ $d$ が大き いと（Fig. 5 (b) $d=2.4$ および(c) 4.8 mm)，長く連続したク ラックが多く見られた。 これに対し，Fig. 5 (a) $d=0.75$ の場 合, クラックは微小かつ断続的であった。

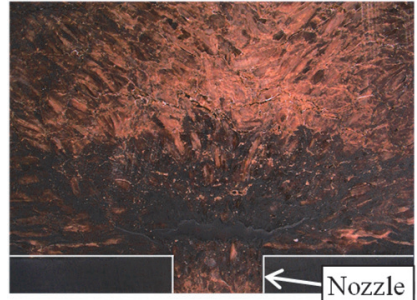

(i) Bottom of container

(a) $d=0.75 \mathrm{~mm}$

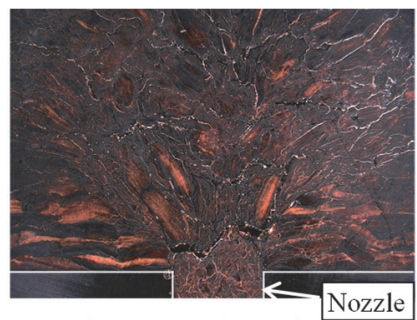

(i) Bottom of container

(b) $d=2.4 \mathrm{~mm}$

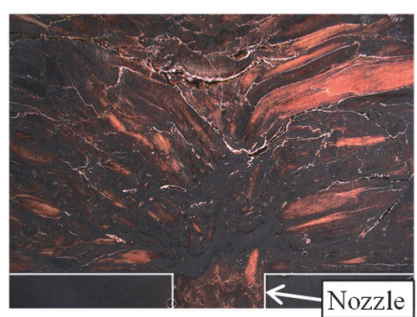

(i) Bottom of container

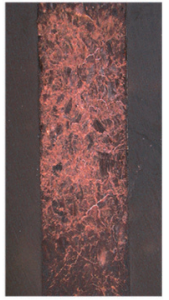

(ii) Nozzle

\section{$3 \mathrm{~mm}$}

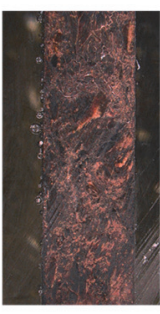

(ii) Nozzle
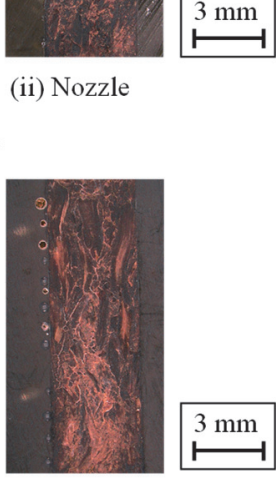

(ii) Nozzle (c) $d=4.8 \mathrm{~mm}$

Fig. 5 Cross section of powder flowing $\left(d_{\mathrm{n}}=4 \mathrm{~mm}\right)$.

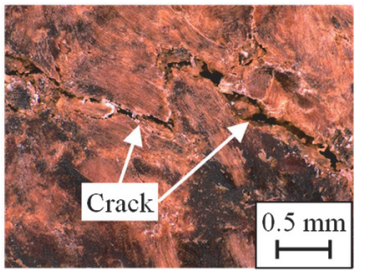

(a) $d=0.75 \mathrm{~mm}(100 \mathrm{x})$

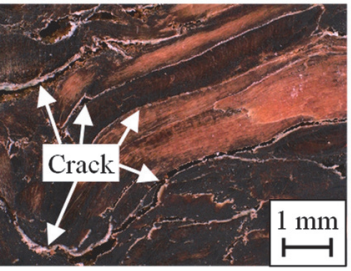

(b) $d=4.8 \mathrm{~mm}(50 \mathrm{x})$
Fig. 6 Appearance of cracks $\left(d_{\mathrm{n}}=4 \mathrm{~mm}\right)$.
Fig. 6 にクラック近傍を拡大した観察像を示す。 (a) $d=0.75$ および(b) $4.8 \mathrm{~mm}$ のいずれにおいても，クラックは 粒子界面に沿って生じていた. 木粉の流動は, 粉砕によっ て得られた元々の粒子界面，もしくは，仮道管などの繊維 界面が滑ることによって，粒子の破砕をともないながら 生じると考えられる.弱部にて滑りは生じるため, 除荷時 に作用する外力, 或いは, 内力の影響によって主な滑り面 が，開口部として現れたと考えられる．Fig. 6 (a) に示す ように, $d=0.75 \mathrm{~mm}$ の場合, 元々の粒子が小さいため, ク ラックが他の粒子にぶつかると折れ曲がっている。これ に対し， $d=4.8 \mathrm{~mm}$ の場合，Fig. 6 (b) に示すように，元々 の粒子が大きいため，粒子に沿ったクラックが長く連続 している，すなわち，長く連続した滑り面が生じやすい $d$ が大きな条件で高い熱流動性が発現したと考えられる.

上記を踏まえ，粒子サイズ $d$ が熱流動性に及ぼす影響

（Fig.4）を考察する. 最も熱流動性が高まる $d=2.4 \mathrm{~mm}$ を 基準に考えると， $d$ が $2.4 \mathrm{~mm}$ より小さいと，流動時に長 く連続した滑り面が生じにくくなるため, $d$ の減少にとも ない熱流動性は低下寸る。一方， $d$ が $0.75 \mathrm{~mm}$ より小さ くなると，熱流動性はやや向上する。これは，木粉の粒子 が微細になっていることから，木粉とバインダの混合時 において，両者がなじみやすくなったためと考えられる. $d$ が $2.4 \mathrm{~mm}$ より大きいと, 長く連続した滑り面が生じや すくなる一方, ノズル流入時における粒子の破砕に必要 な力が大きくなる．このため, $d$ の増加にともない, 熱流 動性は徐々に低下寸る.

\section{4 成 形 試 験}

\section{$4 \cdot 1$ 成形試験方法}

成形試験には, 熱流動試験と同様に, 当研究室にて作製 した装置を使用した．Fig. 7 に装置の概略を示す，パンチ およびノズルには, 合金工具鋼 (SKD11), それ以外の部品 については機械構造用炭素鋼 (S45C) を用いた. Fig. 7 に 示すように，コンテナ内の試料をパンチにてプレスする と，試料がノズルを通してキャビティ内へと流動する。キ ヤビティに試料が完全充填すると, $l_{\mathrm{c}} \times w_{\mathrm{c}} \times h_{\mathrm{c}}$ のプレート が得られる. 試験手順としては, まず試料をコンテナに投 入し, 所定時間 $t_{\mathrm{h}}$ 予熱した. 予熱後, パンチを一定速度 $v_{\mathrm{p}}$ にて押し込み, 試料をキャビティへと流動させた. パンチ 面圧 $P$ が $P_{\max }(200 \mathrm{MPa})$ に達したら，パンチをストップ

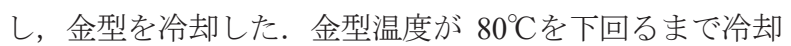
した後に，成形品を金型から取り出した。Table 3 に成形

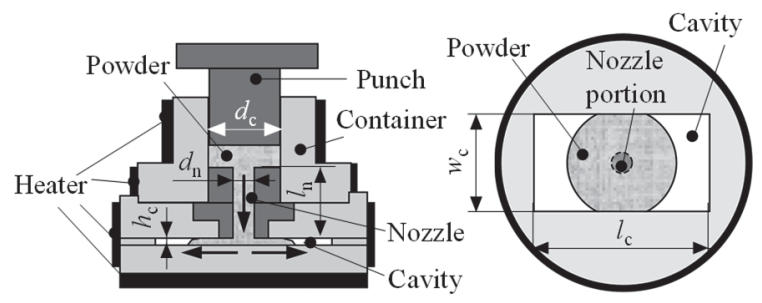

(a) Cross-sectional view of apparatus (b) Upper view of cavity

Fig. 7 Schematic diagram of molding test. 
Table 3 Molding test conditions.

\begin{tabular}{|c|c|}
\hline $\begin{array}{c}\text { Container inner diameter } d_{\mathrm{c}} \\
{[\mathrm{mm}]}\end{array}$ & 30 \\
\hline Nozzle diameter $d_{\mathrm{n}}[\mathrm{mm}]$ & 10 \\
\hline Nozzle length $l_{\mathrm{n}}[\mathrm{mm}]$ & 25 \\
\hline Length of cavity $l_{\mathrm{c}}[\mathrm{mm}]$ & 90 \\
\hline Width of cavity $w_{\mathrm{c}}[\mathrm{mm}]$ & 50 \\
\hline Height of cavity $h_{\mathrm{c}}[\mathrm{mm}]$ & 4 \\
\hline Punch velocity $v_{\mathrm{p}}[\mathrm{mm} / \mathrm{s}]$ & 0.1 \\
\hline Temperature $T\left[{ }^{\circ} \mathrm{C}\right]$ & 180 \\
\hline Pre-heating time $t_{\mathrm{h}}[\mathrm{min}]$ & 5 \\
\hline Quantity of sample $m[\mathrm{~g}]$ & 30 \\
\hline Particle size of wood $d[\mathrm{~mm}]$ & $0.25,2.4,3.4$ \\
\hline Binder content $B[\mathrm{wt} \%]$ & $20,30,40,50$ \\
\hline Maximum pressure $P_{\max }[\mathrm{MPa}]$ & 200 \\
\hline
\end{tabular}

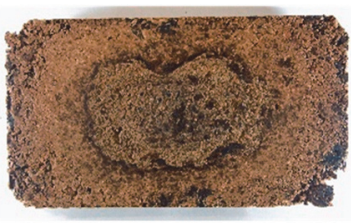

(a) $B=20 \mathrm{wt} \%$

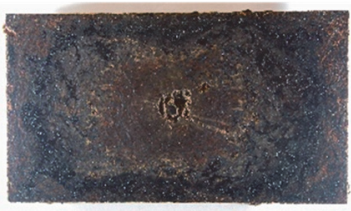

(c) $B=40 \mathrm{wt} \%$

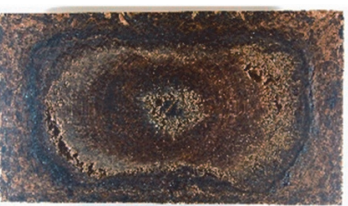

(b) $B=30 \mathrm{wt} \%$

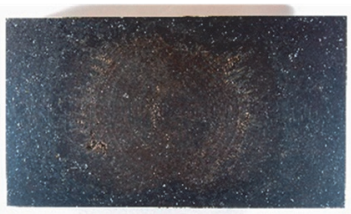

(d) $B=50 \mathrm{wt} \% \quad 10 \mathrm{~mm}$
Fig. 8 Appearances of molded plates (Particle size $d=2.4 \mathrm{~mm}$ ).

条件を示す，粒子サイズ $d$ およびバインダ含有率 $B$ が成 形性に及ぼす影響を調査した。

\section{$4 \cdot 2$ 成形性に及ぼす粒子サイズの影響}

Fig. 8 に, $d=2.4 \mathrm{~mm}$ の場合における代表的な成形品の 外観を示す. バインダ含有率 $B=20 \sim 50 \mathrm{wt} \%$ の範囲で成形 品を得ることが可能であった. $B=40$ および $50 \mathrm{wt} \%$ では, 金型に完全充填しており，色ムラの少ない均一な成形品 が得られた. $B=30 \mathrm{wt} \%$ では, キャビティに完全充填して いるものの, 所々に色の薄い箇所や，凹凸が見られた。成 形品の色の変化は, 加熱によるバインダの反応や, バイン ダ・密度の偏りによって生じる. 金型内において大きな温 度分布がない本実験においては，バインダの反応は場所 によらず均一であったと考えられるため，色の変化は主 にバインダや密度の偏りによるものと考えられる. $B=20$ $\mathrm{wt} \%$ になと, 試料の充填不足によって全体的に色が薄く なり，端部には欠けが生じた。

Table 4 に粒子サイズ $d$ が成形性に及ぼす影響を示す. 成形性は，完全充填（S)，端部未充填（D）およびキャビ ティ内の流動不可 $(\mathrm{F})$ にて評価した. $d=2.4$ および $3.4 \mathrm{~mm}$ では, $B=30 \sim 50 \mathrm{wt} \%$ の範囲で完全充填した成形品が得られ た. しかしながら， $d=0.25 \mathrm{~mm}$ の場合，完全充填が可能な
Table 4 Effect of particle size $d$ on moldability.

\begin{tabular}{|c|c|c|c|}
\hline \multirow{2}{*}{$\begin{array}{c}\text { Binder content } \\
B[\mathrm{wt} \%]\end{array}$} & \multicolumn{3}{|c|}{ Particle size $d[\mathrm{~mm}]$} \\
\cline { 2 - 4 } & 0.25 & 2.4 & 3.4 \\
\hline 20 & $\mathrm{~F}$ & $\mathrm{D}$ & $\mathrm{D}$ \\
\hline 30 & $\mathrm{D}$ & $\mathrm{S}$ & $\mathrm{S}$ \\
\hline 40 & $\mathrm{~S}$ & $\mathrm{~S}$ & $\mathrm{~S}$ \\
\hline 50 & $\mathrm{~S}$ & $\mathrm{~S}$ & $\mathrm{~S}$ \\
\hline
\end{tabular}

S: Success (Completely filling in cavity)

D: With defect (No filling at edge portion)

F: Failure (No flowing into cavity)
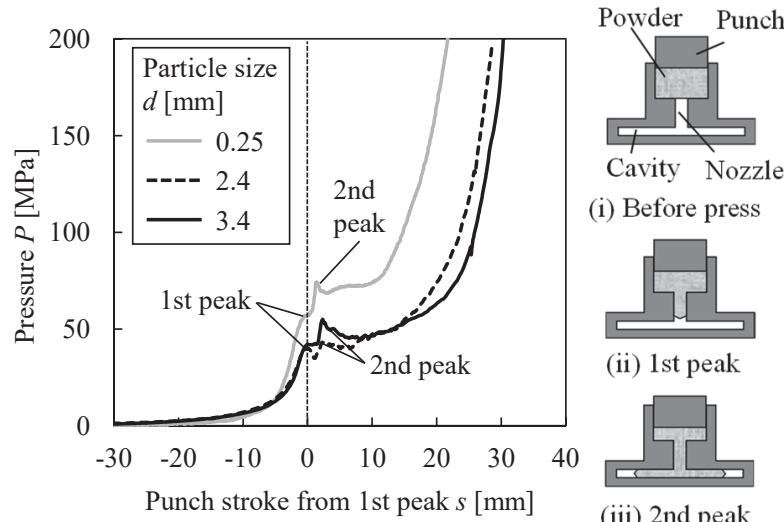

Cavity Nozzle

(i) Before press

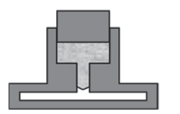

(ii) 1 st peak

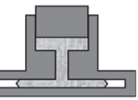

(iii) 2 nd peak

Fig. 9 Effect of particle size $d$ on pressure variation during molding $(B=30 \mathrm{wt} \%)$.

$B$ の範囲は 40 50 wt\%に縮小し， $B=20 \mathrm{wt} \%$ では成形が不 可能であった.

Fig. 9 にバインダ含有率 $B=30 \mathrm{wt} \%$ の場合における成形 時のパンチ面圧 $P$ の変化を示す. いずれの粒子サイズ $d$ の場合においても, 2 回の面圧の折れ曲がり（ピーク）が 確認された。 木粉の成形加工において, Fig. 3 でもみられ たように,ノズルから試料が押し出される際や, 流動方向 が変わる際に圧力のピークが発生する ${ }^{8)}$. 本実験では, 1 回目のピークは試料が流動してノズルから押し出された 点 (Fig. 9 (ii)), 2 回目のピークはキャビティ底部に試料が 到達し, 流動方向が変化した点 (Fig.9 (iii)) と推測できる.

1 回目のピークを本実験における流動開始点と仮定し, ストロークに対するパンチ面圧挙動について考察する. 粒子サイズ $d=2.4$ および $3.4 \mathrm{~mm}$ の場合と比べ, $d=0.25 \mathrm{~mm}$ では成形時におけるパンチ面圧 $P$ が全体的に高い傾向を 示した。 また，最大面圧である $200 \mathrm{MPa}$ に達した際のス トローク $s$ は, $d=0.25 \mathrm{~mm}$ の場合が最も小さい. これは, 試料をキャビテイ端部にまで流し込む前に, $P$ が $P_{\max }(200$ $\mathrm{MPa})$ に達し, 成形を終了したためである. 粒子サイズが 小さい $d=0.25 \mathrm{~mm}$ にて面圧が高くなる傾向は, 流動試験 にて見られた傾向と一致しており，流動試験結果は妥当 であると言える。

本結果を踏まえると, 試料の熱流動性を高めることに よって成形性を改善するためには, 粒子サイズ $d=0.25 \mathrm{~mm}$ まで微粉砕する必要はなく, $d=2.4$ や $3.4 \mathrm{~mm}$ といった比 
較的大きな粒子が望ましいと考えられる．成形性の改善 は成形品の物性向上につながる一方で， $d$ が大きい場合， 成形品に対して Fig. 5 および 6 で見られたような長く連 続したクラックが入りやすい可能性が考えられる。 今後 は良好な成形性を示した粒子サイズの範囲で，粒子サイ ズが成形品の物性に及ぼす影響を検討する必要がある。

\section{5 結言}

天然系バインダであるスクロースおよびクエン酸を混 合したスギ粉末の成形において，粉砕コスト低減および 粒子サイズ適正化を目的として，粒子サイズが熱流動性 に及ぼす影響を調查した。 その結果，以下の知見を得た。

(1) 粒子サイズ $d$ が $0.25 \mathrm{~mm}$ （0.5 mm メッシュパス）か ら $4.8 \mathrm{~mm}$ (4.0 mm メッシュパス, $5.6 \mathrm{~mm}$ メッシュ オン）に至るまで，様々な試料の熱流動試験を行っ た結果，いずれのdにおいても直径 $d_{\mathrm{n}}=2 \mathrm{~mm}$ のノズ ルから試料を流出させることが可能であった。

(2) 粒子サイズ $d$ が熱流動に及ぼす影響は，バインダ含 有率が少ないほど顕著に現れ, 直径 $d_{\mathrm{n}}=2 \mathrm{~mm}$ のノズ ルを用いた場合, $d=2.4 \mathrm{~mm}(2.0 \mathrm{~mm}$ メッシュオン, $2.8 \mathrm{~mm}$ メッシュパス) の際に流動時の圧力が最小と なった. また, $d$ が小さい場合よりも, 大きい場合の 方が全体的に低い流動圧力を示した.

（3）流動物の断面を観察したところ，粒子サイズ $d$ が大 きい場合ほど，流動時における滑り面に起因して発 生したと考えられる長いクラックが確認された。連 続的な長い滑り面の発生が，熱流動性の向上に寄与 すると考えられる.

(4) 粒子サイズ $d$ が異なる木粉を用いて成形試験を試み た結果, $d$ が小さい木粉 $(d=0.25 \mathrm{~mm})$ よりも，大き い木粉（ $d=2.4 \mathrm{~mm}$ や, $3.4 \mathrm{~mm}(2.8 \mathrm{~mm}$ メッシュオ ン, $4.0 \mathrm{~mm}$ メッシュパス)) の方が型への充填性が 良好であった。これは， $d$ が大きい木粉の方が，成形 時における試料の流動圧力が低いためである.

（5）成形時における試料の熱流動性を高めることによっ て, 型への充填性を高めるためには, 必要以上に素 材を微粉砕する必要はなく, 適正な粒子サイズが存 在する.

本研究は JSPS 科研費 16K18265, および京都大学生存 圈研究所 2016 年度生存圈ミッション研究としての助成 を受け, 実施したものである。ここに記して謝意を表す。

\section{参 考 文 献}

1) H. Yamakawa, "Policies against single-use plastics: overview of EU and other countries", Material Cycles and Waste Management Research, Vol.29, Issue 4, pp. 294-303 (2018).

2) Y. Yuyama, "Carbon neutral", Journal of the Agricultural Engineering Society, Japan, Vol.71, Issue 8, p.762 (2003).

3) T. Takayama, "Introduction", Journal of the Japan Society for Technology of Plasticity, Vol.56, Issue 657, pp.882-884 (2015).

4) K. Kojiro and Y. Furuta, "Wood plastic composite and its trend in standardization", Journal of the Japan Society for Technology of Plasticity, Vol.55, Issue 637, pp.98-102 (2014).

5) O. V. Startsev, B. N. Salin, Yu. G. Skunridin, R. M. Utemesov and A. D. Nasonov, "Physical properties and molecular mobility of the new wood composite plastic "thermobalite"', Wood Science and Technology, Vol.33, pp.73-83 (1999).

6) I. Takahashi, Y. Tomita, T. Sugimoto, Y. Kikata and Y. Sasaki, "Thermoplastic flow behavior of steamed wood flour under heat and compression", Wood Science and Technology, Vol.44, pp.607-619 (2010).

7) S. Okada, T. Iizuka, K. Yamaishi, M. Mitani, T. Miki and N. Takakura, "Examination of injection molding properties of nozzle and attempt of product filling into mold in injection molding of only steamed bamboo powder", Journal of the Japan Society for Technology of Plasticity, Vol.53, Issue 620, pp.821-825 (2012).

8) S. Kajikawa and T. Iizuka, "Injection molding using only $200{ }^{\circ} \mathrm{C}$ steamed bamboo powder by controlling metal mold temperature", Procedia Engineering, Vol.81, pp.1186-1191 (2014).

9) S. Kajikawa and T. Iizuka, "Effect of water-soluble components mass on the fluidity of the steam-treated bamboo powder caused by heating and compression", Journal of the Society of Materials Science, Japan, Vol.64, Issue 5, pp.381-386 (2015).

10) S. Kajikawa, M. Horikoshi, S. Tanaka, K. Umemura and K. Kanayama, "Molding of wood powder with a natural binder", Procedia Engineering, Vol.207, pp.113-118 (2017).

11) S. Kajikawa, M. Horikoshi, T. Kuboki, S. Tanaka, K. Umemura and K. Kanayama, "Fabrication of naturally derived wood products by thermal flow molding of wood powder with sucrose and citric acid", BioResources, Vol.15, Issue 1, 1702-1715 (2020).

12) P. S. Bailey and C. A. Bailey, "Organic chemistry - A brief survey of concepts and applications-", Fourth Edition, Chapter 10 (1989) Allyn and Bacon.

13) K. Umemura, O. Sugihara and S. Kawai, "Investigation of a new natural adhesive composed of citric acid and sucrose for particleboard", Journal of Wood Science, Vol.59, pp.203-208 (2013).

14) K. Umemura, O. Sugihara and S. Kawai, "Investigation of a new natural adhesive composed of citric acid and sucrose for particleboard II: effects of board density and pressing temperature", Journal of Wood Science, Vol.61, pp.40-44 (2015). 